\title{
Implementasi Fitur Haar-like dalam Mendeteksi dan Menghitung Jumlah Orang pada Noised Digital Image
}

\author{
Qisthi Al Hazmi Hidayatur Rohman \\ Teknik Telekomunikasi, Institut Teknologi Telkom Purwokerto \\ Jl. DI. Panjaitan 128 Purwokerto, Indonesia \\ qisthi@ittelkom-pwt.ac.id
}

Accepted on September 28, 2018

\begin{abstract}
Mendeteksi objek pada citra digital bagi manusia pada umumnya merupakan hal yang tidak sulit, namun tidak bagi komputer. Komputer membutuhkan teknologi khusus untuk mengolah suatu citra hingga dapat mendeteksi objek pada citra digital. Visi komputer memberikan solusi pada komputer untuk dapat mendeteksi objek pada citra digital. Salah satu fitur yang dapat diimplementasikan adalah Fitur Haar-like. Dengan fitur Haar-like, komputer akan mengekstraksi citra digital yang nantinya akan dideteksi suatu objek pada citra tersebut dengan algoritma ViolaJones, yaitu algoritma cascade classifier yang berfungsi untuk mendeteksi suatu objek pada citra berdasarkan data citra terlatih (trained data). Pada penelitian ini, Fitur Haar dapat mendeteksi objek pada citra digital dengan tiga kondisi yang berbeda, yaitu saat kondisi normal, kondisi citra dengan derau, dan kondisi citra dengan pencahayaan rendah. Visi komputer dengan Fitur Haarlike dapat mendeteksi objek pada ketiga kondisi citra tersebut dengan prosentase kesalahan yang cukup rendah.
\end{abstract}

Kata Kunci: Visi Komputer, Citra Digital, Derau, Haar-like

\section{PENDAHULUAN}

$\mathbf{M}$ endeteksi orang pada sebuah citra digital merupakan hal yang mudah bagi penglihatan manusia, namun tidak bagi komputer. Dengan visi komputer, komputer akan diprogram untuk mendeteksi serta menghitung jumlah orang pada sebuah citra [1]. Dengan mengizinkan komputer melakukan hal tersebut, maka akan memudahkan kerja manusia dalam menghitung orang pada sebuah citra digital yang terdiri dari banyak orang, seperti pada jalan raya. Jika hanya satu citra maka manusia akan mudah untuk menghitung, namun bayangkan jika citra yang disediakan lebih dari 1000, maka akan dibutuhkan waktu yang lebih panjang. Untuk dapat memungkinkan komputer mendeteksi serta menghitung jumlah orang pada sebuah citra digital, teknologi visi komputer dapat diimplementasikan pada komputer, khususnya dengan menggunakan Fitur Haar pada citra digital [1].

Tujuan dari penulisan ini adalah untuk menguji kinerja dari Fitur Haar dalam mendeteksi objek orang pada citra digital. Komputer akan diprogram sesuai dengan kebutuhan yang diinginkan, yakni untuk mendeteksi orang pada suatu citra digital dengan fitur Haar. Pada penelitian ini, penulis akan melakukan tiga pengujian yang berbeda pada citra digital untuk mendeteksi orang pada citra digital dengan Fitur Haar yaitu: 1. citra terang tanpa noise (normal), 2. citra dengan derau (dengan variasi jumlah derau 0.01, 0.025, 0.05, 0.075, 0.1), 
dan 3. citra dengan intensitas cahaya (brightness) yang rendah dengan gamma yang disesuaikan yakni 0.75 , $0.5,0.25$, dan 0.1 . Derau atau noise yang digunakan pada penelitian ini adalah salt and pepper noise.

\section{TINJAUAN PUSTAKA}

\section{A. Visi Komputer}

Visi Komputer merupakan salah satu interdisiplin keilmuan yang mengajarkan komputer bagaiamana untuk memahami citra ataupun video digital. Komputer tidak dapat memahami citra maupun video digital. Dengan metode yang disajikan Visi Komputer, Komputer dapat diprogram untuk memahami suatu citra digital dengan metode yang dikenal sebagai pengolahan citra. Citra yang sudah diolah oleh komputer, selanjutnya dipahami oleh komputer dengan metode kecerdasan buatan, dengan kata lain visi komputer merupakan gabungan dari pengolahan citra dan kecerdasan buatan [2].

Skema tugas visi komputer terdiri dari metode akuisisi, pengolahan, analisa, dan memahami citra digital [1]. Skema tugas tersebut memungkinkan visi komputer untuk mendeteksi suatu objek tertentu pada suatu citra digital, baik objek orang, maupun objek lainnya seperti pisang, ponsel, dan lain sebagainya.

\section{B. Fitur Haar-like}

Fitur Haar-like merupakan fitur yang digunakan, pada komputer visi, untuk mendeteksi suatu objek pada citra digital. Paul Viola dan Michael Jones [3] mengenalkan fitur Haar-like ini pada tahun 2001 yang algoritmanya disebut Viola Jones Algorithm yang digunakan untuk mendeteksi objek dengan cepat (rapid detection) [1]. Fitur Haar-like awalnya digunakan untuk mendeteksi wajah manusia (face detection), namun saat ini fitur Haar-like digunakan untuk mendeteksi objek lain selain wajah manusia, yakni orang (body) dan lain sebagainya.

Algoritma Viola-Jones menggunakan pengklasifikasi kaskade untuk mendeteksi suatu objek pada citra digital. Algoritma ini membutuhkan citra positif dan citra negative untuk melatih classifier yang nantinya dibutuhkan untuk mengekstrak fitur dari data tersebut [4]. Gambar menunjukkan beberapa tipe fitur yang digunakan untuk mendeteksi objek dengan fitur Haar-like. Setelah mendapatkan region of interest dari setiap kesamaan citra positif, keluarannya dapat digunakan untuk mendeteksi juga menghitung objek yang diinginkan.

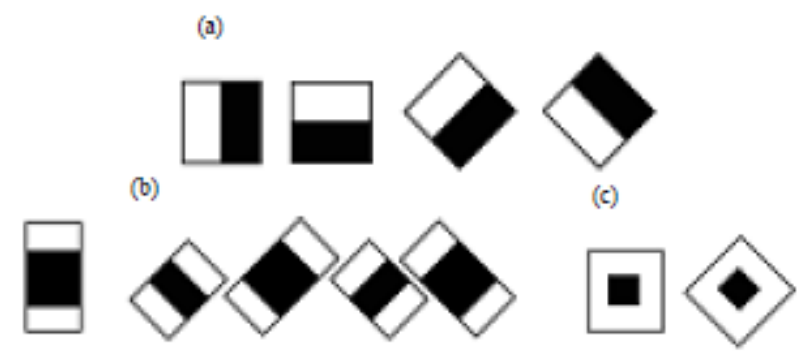

Gambar 1. Jenis Fitur Haar-like: a) sudut; b) garis; c) center surrounded [4]

\section{Derau Garam dan Merica}

Derau atau Noise pada citra dapat berupa aditif atau duplikatif, tergantung pada bagaimana citra terbentuk [2]. Derau impuls adalah salah satu jenis derau aditif yang ada pada citra yang dikarenakan oleh kesalahan bit dalam transmisi. Pada citra digital, terdapat dua jenis derau impuls yaitu derau dengan nilai acak dan derau dengan nilai tetap, yang dikenal sebagai derau garam dan merica (salt and pepper noise). Pada derau garam dan merica, piksel yang rusak mengambil nilai maksimum (255) atau minimm (0), sehingga menyebabkan bintik hitam dan putih pada citra [6]. Berdasarkan teori di atas, dapat dituliskan sebuah formula untuk derau garam dan merica [7]: 


$$
P D F_{\text {sait leppper }}=\left\{\begin{array}{l}
A \text { for } g=a(\text { "pepper" }) \\
B \text { for } g=b(\text { "salt" })
\end{array}\right.
$$

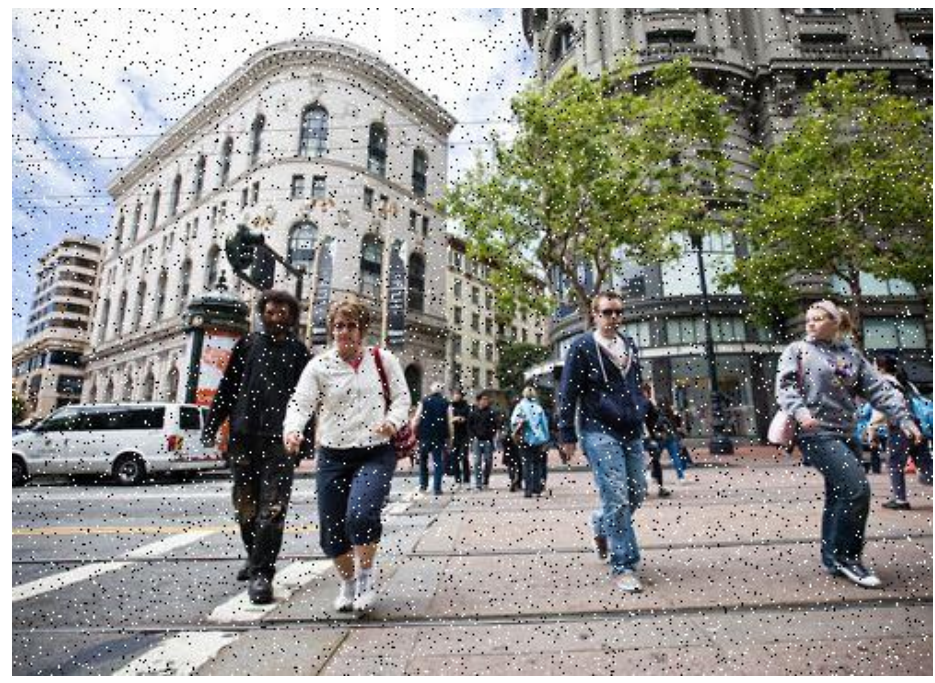

Gambar 2. Citra dengan Derau Salt and Pepper

\section{METODE PENELITIAN}

Penelitian ini menggunakan sistem operasi Linux Ubuntu 16.04 dengan Bahasa pemrograman Python dan library OpenCV yang digunakan untuk mengolah dan mengekstrasi citra digital serta mendeteksi serta menghitung jumlah orang pada citra digital yang dimasukkan dengan komputer visi. Dalam mengimplementasi fitur Haar-like dibutuhkan sekumpulan data terkait, di penelitian ini adalah data orang, yang penulis dapatkan dari internet. Data dilatih dengan fitur cascadetraining yang tersedia di dalam OpenCV untuk menghasilkan trained data yang nantinya akan digunakan untuk mendeteksi orang pada citra yang dimasukkan [2].

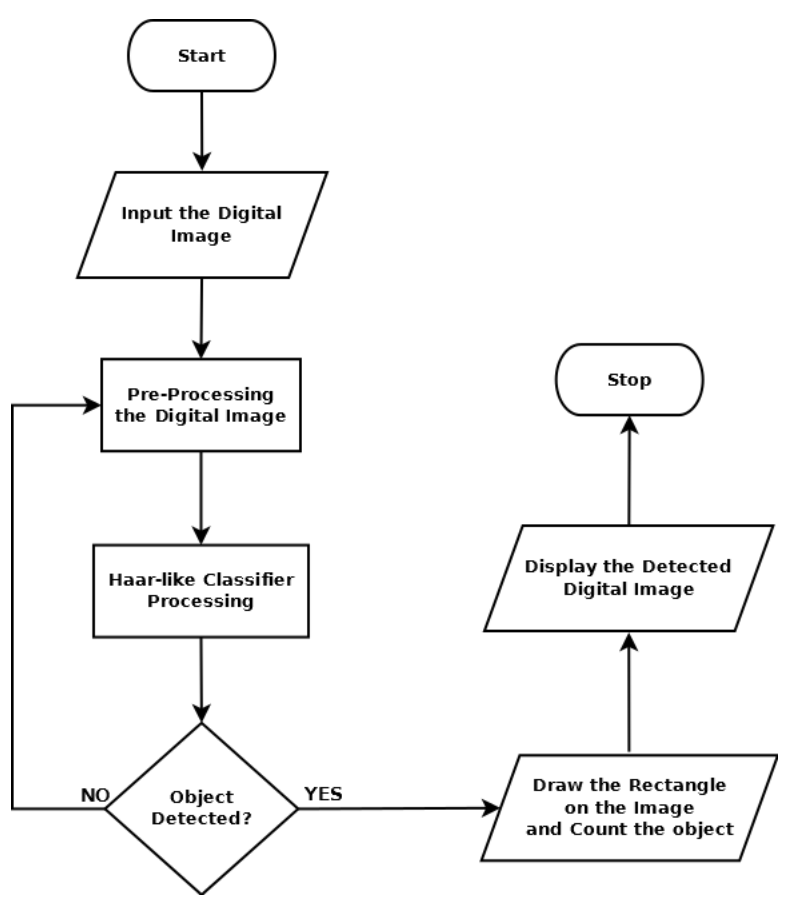


Pada alur sistem di Gambar 2, citra yang dimasukkan akan diproses oleh program, yakni citra digital diubah menjadi citra hitam putih (RGBtoGRAY). Citra yang telah diubah menjadi citra hitam putih akan diproses menggunakan pengklasifikasi fitur Haar. Fitur Haar akan mendeteksi Region of Interest citra tersebut berdasarkan data yang diharapkan, pada penulisan ini ROI pada orang (person detection). Jika objek terdeteksi pada citra, proses selanjutnya adalah memberikan gambar kotak pada citra yang sudah diproses, lalu citra yang sudah diberi gambar kotak ditampilkan sebagai keluaran.

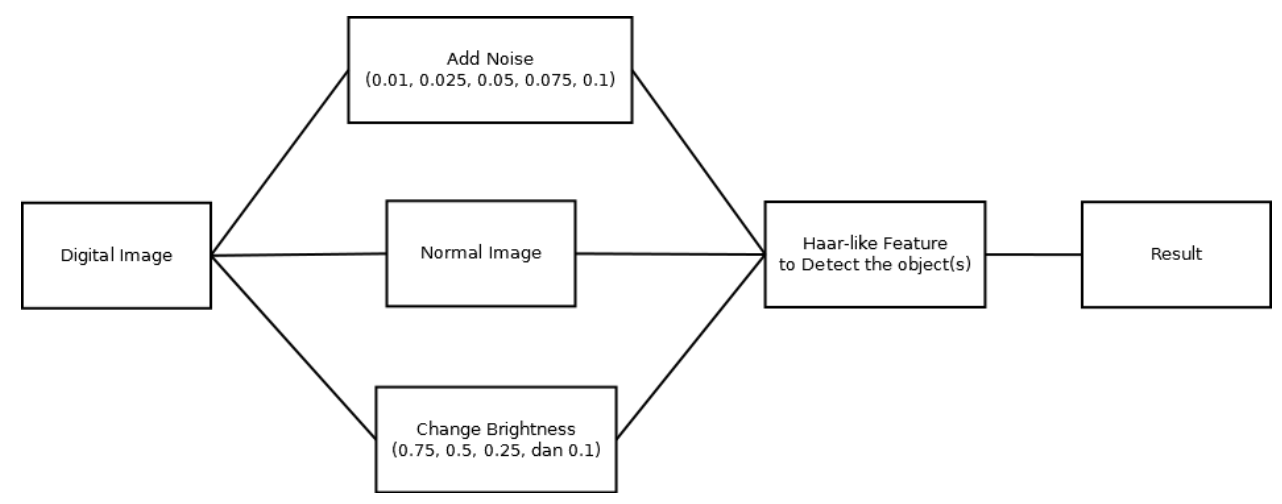

Gambar 4. Skema Pengujian Sistem

Pada penelitian ini, penulis mengambil citra digital dengan objek manusia secara acak. Pada penelitian ini, penulis menggunakan 3 skema pengujian dengan kondisi citra yang berbeda, yakni kondisi 1: citra dengan intensitas cahaya yang baik, citra dengan derau garam dan merica (dengan variasi jumlah derau 0.01, 0.025, $0.05,0.075,0.1$ ), dan citra dengan intensitas cahaya (brightness) yang rendah dengan gamma yang disesuaikan yakni $0.75,0.5,0.25$, dan 0.1 . Jumlah citra yang akan digunakan sebanyak lima citra, citra dengan satu objek orang, dua objek orang, tiga objek orang, empat objek orang, dan lima objek orang.

\section{HASIL DAN PEMBAHASAN}

\section{A. Menambahkan Derau pada Citra Digital}

Derau yang digunakan pada penelitian ini adalah derau garam dan merica (salt and pepper noise). Derau garam dan merica menyebabkan citra digital memiliki titik-titik hitam dan putih yang tersebar secara acak dengan jumlah (probability) yang berbeda-beda. Pada penelitian ini, penulis memberikan jumlah kemungkinan terjadinya derau dengan nilai yang berbeda-beda, yaitu $0.01,0.025,0.05,0.075,0.1$. Semakin tinggi nilai probability-nya, maka derau pada citra akan semakin banyak. Gambar 5 di bawah menunjukkan bahwa semakin tinggi nilai probability-nya maka jumlah derau yang muncul pada citra semakin banyak, nilai dibatasi hanya sampai 0.1, karena jika lebih dari itu maka citra asli tersebut tidak akan terlihat dengan jelas. Berikut adalah hasilnya. 


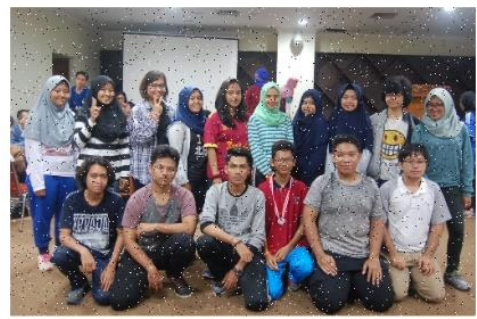

(a)

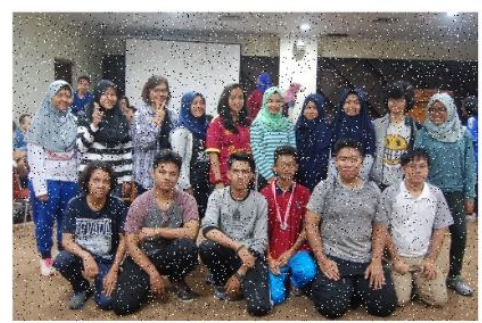

(b)

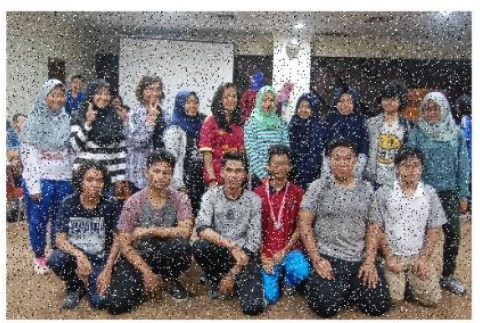

(c) (d)

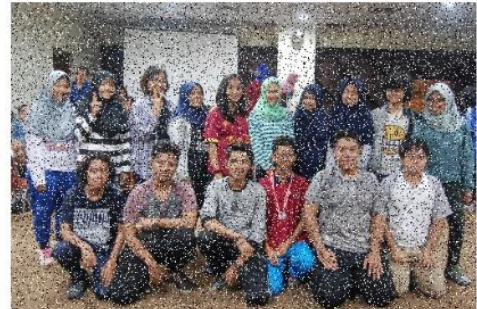

(e)

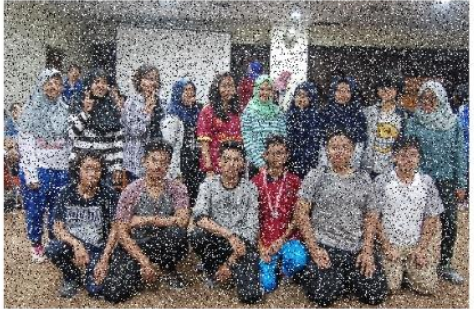

Gambar 5. Citra dengan Probability Derau: (a) 0.01, (b) 0.025, (c) 0.05, (e) 0.075, (d) 0.1

B. Mengubah Pencahayaan (Brightness) pada Citra dengan Mengubah Nilai Gamma

Gamma pada citra digital dapat diatur untuk mengatur tingkat kecerahan (brightness) pada citra digital. Pada penelitian ini, penulis mengubah tingkat pencahayaan pada citra yang nantinya dilakukan deteksi objek orang pada citra digital. Nilai gamma yang digunakan adalah: $0.75,0.5,0.25$, dan 0.1 . Semakin rendah tingkat gamma-nya, maka akan semakin gelap citra digital tersebut. Gambar 6 menunjukkan perubahan tingkat kecerahan (brightness) pada citra digital.

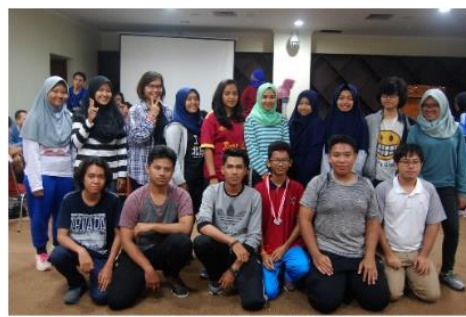

(a)

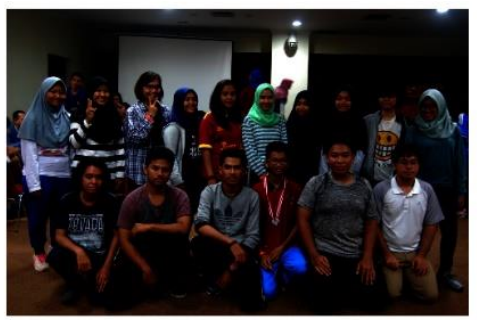

(c)

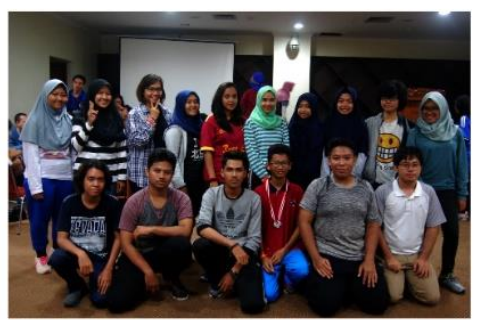

(b)

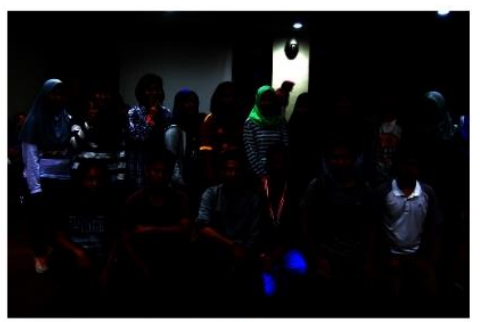

(d)

Gambar 6. Citra dengan tingkat gamma: (a) 0.75, (b) 0.5, (c) 0.25, (d) 0.1

\section{Perbandingan Hasil Deteksi dengan Fitur Haar}

Tiga citra digital diberikan tiga kondisi yang berbeda, yaitu pertama adalah kondisi normal, di mana citra digital tidak diberikan kondisi apapun, kedua adalah kondisi citra dengan derau garam dan merica yang sudah 
dijelaskan pada subbab A, dan ketiga adalah kondisi citra dengan tingkat pencahayaan yang berbeda seperti pada gambar 6 di subbab B. Tabel 1 menunjukkan perbandingan hasil deteksi orang serta menghitung jumlah orang pada citra digital yang dikondisikan dengan tiga kondisi yang berbeda. Pada citra normal, objek dapat terdeteksi dengan baik sedangkan pada citra dengan derau, objek yang terdeteksi bernilai acak, tergantung jumlah probability derau yang ditampilkan pada citra, dan pada citra dengan pencahayaan lebih rendah, objek terdeteksi dengan jumlah yang berbeda-beda, tergantung dari nilai gamma pada pencahayaan citra digital.

Tabel 1. Perbandingan Hasil Deteksi Citra Digital pada Tiga Kondisi Berbeda

\begin{tabular}{|c|c|c|c|c|c|c|c|c|c|c|}
\hline & \multicolumn{2}{|c|}{ Citra 1 orang } & \multicolumn{2}{|c|}{ Citra 2 orang } & \multicolumn{2}{|c|}{ Citra 3 orang } & \multicolumn{2}{|c|}{ Citra 4 orang } & \multicolumn{2}{|c|}{ Citra 5 orang } \\
\hline & Detect & $\mathrm{T}(\mathrm{s})$ & Detect & $T(s)$ & Detect & $\mathrm{T}(\mathrm{s})$ & Detect & $\mathrm{T}(\mathrm{s})$ & Detect & $\mathrm{T}(\mathrm{s})$ \\
\hline Normal & 1 & 0.122 & 2 & 0.315 & 3 & 0.228 & 4 & 0.208 & 5 & 0.353 \\
\hline S\&P 0.01 & 1 & 0.383 & 2 & 0.331 & 3 & 0.256 & 3 & 0.339 & 5 & 0.502 \\
\hline S\&P 0.025 & 1 & 0.402 & 1 & 0.355 & 3 & 0.301 & 2 & 0.332 & 3 & 0.626 \\
\hline S\&P 0.05 & 1 & 0.392 & 1 & 0.393 & 1 & 0.314 & 2 & 0.338 & 1 & 0.652 \\
\hline S\&P 0.075 & 2 & 0.385 & 0 & 0.292 & 1 & 0.323 & 1 & 0.331 & 1 & 0.607 \\
\hline S\&P 0.1 & 1 & 0.383 & 0 & 0.316 & 1 & 0.338 & 0 & 0.326 & 0 & 0.597 \\
\hline Bright: 0.75 & 1 & 0.16 & 1 & 0.311 & 3 & 0.279 & 3 & 0.182 & 5 & 0.355 \\
\hline Bright: 0.5 & 1 & 0.154 & 1 & 0.349 & 2 & 0.253 & 2 & 0.225 & 4 & 0.336 \\
\hline Bright: $\mathbf{0 . 2 5}$ & 1 & 0.136 & 0 & 0.297 & 2 & 0.249 & 1 & 0.242 & 2 & 0.316 \\
\hline Bright: 0.1 & 0 & 0.068 & 0 & 0.253 & 0 & 0.208 & 1 & 0.226 & 1 & 0.345 \\
\hline
\end{tabular}

\section{Kesimpulan}

Berdasarkan Tabel 1, dapat disimpulkan bahwa Fitur Haar dapat mendeteksi serta menghitung objek pada citra digital, baik citra normal, citra gelap, maupun citra dengan derau. Persentase deteksi Fitur Haar pada setiap kondisi citra bervariasi, semakin gelap maka Fitur Haar akan kesulitan dalam mendeteksi objek, sehingga objek yang terdeteksi kurang dari jumlah objek sebenarnya sedangkan pada citra dengan derau garam dan merica, Fitur Haar cukup baik dalam mendeteksi objek, di mana persentasenya tidak jauh berbeda dengan persentase deteksi pada citra normal. Akan tetapi, citra dengan jumlah objek orang yang lebih banyak, citra dengan derau tidak begitu baik terdeteksi objeknya, dikarenakan beberapa faktor, salah satunya adalah kepadatan objek (jumlah objek yang banyak pada citra dengan ukuran tertentu).

\section{ACKNOWLEDGMENT}

Penulis ingin menyampaikan terima kasih kepada seluruh civitas Fakultas Teknik Telekomunikasi dan Teknik Elektro, khususnya Program Studi S1 Teknik Telekomunikasi Institut Teknologi Telkom Purwokerto atas dukungan kepada penulis. 


\section{REFERENCES}

[1] Singh Dushyant K., dan Kushwaha Dharmender S., “Analysis of Face Feature based Human Detection Techniques”, IJCTA, 9(22), 2016, pp. 173-180.

[2] Dawson-Howe Kenneth, "A Practical Introduction to Computer Vision with OpenCV”, Wiley, 2014.

[3] Jones Michael, dan Viola Paul, "Rapid Object Detection using a Boosted Cascade of Simple Features", Proceesings of the 2001 IEEE Computer Society Conference on Computer Vision and Pattern Recognition, CVPR 2001, Kauai, HI, USA, 2001, pp. I-I.

[4] Utaminingrum Fitri, Primaswara Renaldi, dan Sari Yuita A., "Image Processing of Rapidly Eye Detection based on Robust Haar Sliding Window", International Journal of Electrical and Computer Engineering (IJECE), Vol. 7, No. 2, April 2017, pp. 823-830.

[5] Iqbal Mohammad, Yuwono Rudi T., Fadhillah Hadyan M., dan Widiyanto Sigit, "Realtime Stereo Vision for Vehicle Detection, Classification and Counting Using Raspberry Pi", Journal of Engineering and Applied Sciences, 12 (8), 2207-2213, 2017.

[6] Sathua Sujaya Kumar, Arabinda Dash, dan Aishwaryarani Behera, "Removal of Salt and Pepper noise from Gray-Scale and Color Images: An Adaptive Approach", IJCST, Vol. 5, Issue 1, Jan-Feb 2017.

[7] Zhang Peixuan, dan Li Fang, "A New Adaptive Weighted Mean Filter for Removing Salt-and-Pepper Noise", IEEE Signal Processing Letters, Vol. 21, No. 10, October 2014. 